\title{
PEMBENTUKAN TITANIUM NITRIDA(TiN) DENGAN PROSES NITRIDING PADA TITANIUM MURNI MENGGUNAKAN PLASMA DENSITAS TINGGI
}

\author{
Josephine M. Windajanti ${ }^{1,2}$, D.J. Djoko H. Santjojo ${ }^{1}$, Abdurrouf ${ }^{1}$ \\ ${ }^{1}$ Universitas Brawijaya, Jalan Veteran, Malang-65145 \\ ${ }^{2}$ SMAK Santa Maria Malang, Jalan Raya Langsep 41, Malang-65116 \\ E-mail: joce_win@yahoo.com
}

\begin{abstract}
Pure titanium has been widely utilized in industry but its products suffered from low wear and erosion resistance. The plasma nitriding was selected as a tool to harden the pure titanium products but typically high temperature processing was required to attain high hardness. In the present study, high density plasma nitriding system was applied to make low temperature plasma nitriding at $723 \mathrm{~K}$ (or $450^{\circ} \mathrm{C}$ ) for $14.4 \mathrm{ks}$ (or 4 hours). The average measured hardness reached to $624 \mathrm{HV}$. This high hardness of plasma-nitrided pure titanium at low temperature was attributed to formation of fine TiN precipitates and nitrogen solid solution into vacancy sites in the HCP crystalline structure of titanium.
\end{abstract}

Keywords: titanium murni, sistem plasma RF-DC, nitriding temperatur rendah, kekerasan permukaan, titanium nitride (TiN).

\section{PENDAHULUAN}

Titanium adalah logam yang sangat atraktif karena merupakan logam yang ringan tetapi mempunyai properti yang tangguh. Dalam bidang industri, titanium digunakan sebagai komponen untuk konstruksi pesawat, sistem pipa pada industri petrokimia, kilang minyak lepas pantai, dan alat olah raga. Dalam bidang kesehatan, titanium juga digunakan sebagai tulang buatan atau implan karena sifatnya yang bio kompatibel [1]. Tetapi secara tribologis, titanium murni mempunyai kelemahan yaitu tidak tahan geseran dan mudah tererosi karena tingkat kekerasan permukaannya yang rendah [2], sekalipun dengan mereduksi ukuran partikel pada material titanium akan meningkatkan HV. ketangguhannya.

Titanium mempunyai dua alotropi: pada suhu kamar titanium berada pada struktur kristal hexagonal close-packed (HCP) yang dikenal sebagai fase alfa, dan pada suhu $883{ }^{\circ} \mathrm{C}$ struktur ini akan berubah menjadi struktur body-centered cubic (BCC) yang dikenal sebagai fase beta [3]. Pada dasarnya, titanium juga merupakan logam yang tahan korosi, karena saat kontak dengan udara terbentuk lapisan titanium oksida $\left(\mathrm{TiO}_{2}\right)$ yang stabil pada permukaannya.
Rendahnya tingkat kekerasan permukaan titanium dapat ditingkatkan dengan melakukan proses termokimia yaitu nitriding. Beberapa teknik nitriding telah dikembangkan saat ini, misalnya gas nitriding, laser nitriding dan plasma nitriding. Yoshida, et al. melaporkan peningkatan kekerasan permukaan titanium hingga nilai $620 \mathrm{HV}$ dengan menerapkan gas nitriding pada suhu $800{ }^{\circ} \mathrm{C}$ dengan laju aliran gas sebesar 1,5 liter/menit [4]. Sedangkan Yilmazer, et al. melaporkan suatu proses modifikasi permukaan dengan menggunakan plasma DC berpotensial $2 \mathrm{kV}$ pada suhu $800^{\circ} \mathrm{C}$ selama 9 jam [5]. Hasilnya, kekerasan permukaan titanium meningkat hingga mencapai nilai 2050

Faktor yang sangat menentukan untuk peningkatan kekerasan permukaan titanium adalah terbentuknya suatu presipitasi dari $\varepsilon-\mathrm{Ti}_{2} \mathrm{~N}$ and $\delta$-TiN sebagai lapisan nitrida $[2,5]$. Pembentukan lapisan nitrida hasil proses nitriding ini biasanya membutuhkan proses bersuhu tinggi, meskipun penggunaan suhu tinggi akan menyebabkan kerusakan pada struktur kristal titanium. Proses suhu tinggi juga beresiko terhadap terjadinya kontaminasi oksidasi terhadap permukaan saat berlangsungnya proses nitriding [6]. Selain itu proses pemanasan dan pendinginan kembali 
pada proses bersuhu tinggi juga memerlukan waktu proses yang panjang, sehingga dibutuhkan energi yang tinggi untuk proses tersebut. Proses nitriding dengan bantuan plasma merupakan salah satu proses yang menjanjikan secara komersial karena termasuk proses yang hemat energi dan hemat pada penggunaan gas untuk prosesnya. Saat ini, besarnya konsumsi energi masih menjadi tantangan untuk proses modifikasi permukaan sehingga hal ini menjadi salah satu faktor pendorong untuk optimalisasi proses plasma nitriding [6].

Pada penelitian ini, suatu proses nitriding titanium murni dilakukan pada suhu rendah sebesar $450^{\circ} \mathrm{C}$ dengan memanfaatkan plasma densitas tinggi. Plasma yang digunakan untuk proses nitriding dibangkitkan oleh gabungan dua generator yaitu RF dan DC. Selain itu ditambahkan suatu perangkat hollow cathode untuk meningkatkan densitas plasma yang dihasilkan sehingga peningkatan kekerasan permukaan dapat lebih maksimal. Pengaturan parameter proses juga dilakukan untuk mendapatkan hasil yang optimum pada proses nitriding suhu rendah ini. Dalam penelitian ini tegangan RF diatur pada nilai tertinggi $250 \mathrm{~V}$ sedangkan tegangan bias DC pada nilai $-600 \mathrm{~V}$. Dengan proses selama 4 jam, pada kondisi ini didapatkan peningkatan kekerasan permukaan hingga $625 \mathrm{HV}$.

\section{METODOLOGI PENELITIAN Alat dan Bahan}

Pada penelitian ini digunakan sistem plasma densitas tinggi yang dibangkitkan dengan generator RF dan DC untuk melakukan proses nitriding pada temperatur rendah. Bagian ruang vakum untuk tempat proses mempunyai sepasang dipol RF dan plat katoda yang diberi tegangan bias. Suatu glow discharge plasma dibangkitkan oleh generator RF dengan frekuensi sebesar $2 \mathrm{MHz}$. Tegangan dan arus pada input-output matching diatur otomatis secara elektronik. Gas yang digunakan untuk proses nitriding adalah campuran gas nitrogen dan gas hidrogen dengan laju aliran gas yang diatur secara otomatis oleh rangkaian elektronik sehingga sesuai dengan tekanan total pada proses. Sistem plasma densitas tinggi yang digunakan pada penelitian ini, dikembangkan oleh T. Aizawa dan Y. Sugita mulai tahun 2011 di LLC Nano Film \& Coat Laboratory, Ota-ku, Japan [7]. Diagram sistem plasma yang digunakan untuk proses nitriding pada penelitian ini dapat dilihat pada Gambar 1.

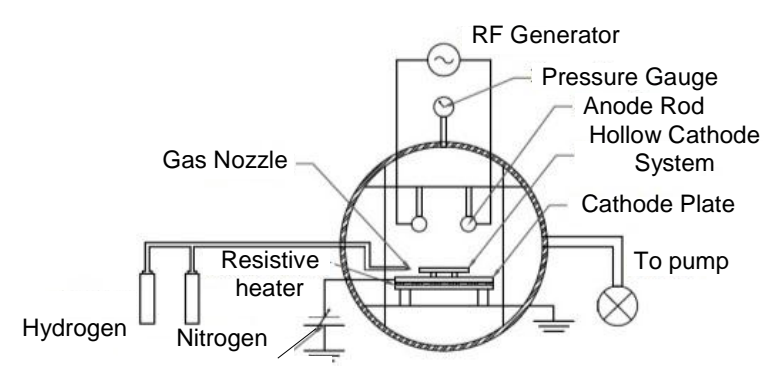

DC Bias Generator

\section{Gambar 1. Sistem plasma RF-DC berdensitas tinggi}

Spesimen yang digunakan pada proses nitriding adalah plat titanium murni dengan ukuran $18 \times 40 \times 0.3 \mathrm{~mm}^{3}$. Spesimen ini ditempatkan di dalam perangkat hollow cathode yang berupa tabung dengan penampang persegi panjang tanpa tutup. Gambar 2 menunjukkan set-up eksperimental yang digunakan pada proses nitriding terhadap titanium murni pada penelitian ini. Tabung hollow cathode ini disangga pada posisi 30 $\mathrm{mm}$ di atas plat katoda yang terhubung dengan generator bias DC.

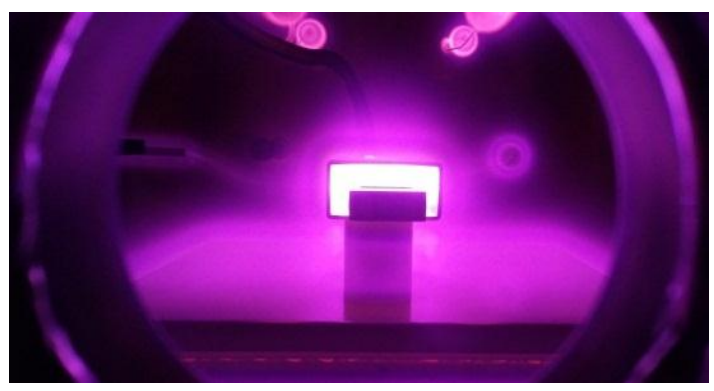

Gambar 2. Pengaturan spesimen dalam perangkat hollow cathode beserta spesimen saat dipapar plasma dalam chamber

\section{Prosedur Eksperimen}

Untuk persiapan sampel, mula-mula sampel dibersihkan dengan larutan alkali (industrial soap) dalam mesin pembersih ultrasonik selama 5 menit sehingga sampel bebas dari lemak dan pengotor lainnya. 
Setelah sampel dibilas, sampel dicelupkan titanium berupa nilai rata-rata dari tingkat dalam alkohol dan dikeringkan. Interior dari kekerasan pada lima posisi di permukaan chamber vakum juga dibersihkan dengan sampel seperti pada Gambar 3.

alkohol.

Spesimen titanium yang telah dirangkai dalam perangkat hollow cathode dimasukkan ke dalam chamber, kemudian proses diawali dengan memvakumkan chamber hingga tekanan dasar sebesar $0,7 \mathrm{~Pa}$ untuk mengeluarkan gas oksigen dari dalam chamber. Setelah itu, dilakukan pemanasan spesimen hingga mencapai suhu $450{ }^{\circ} \mathrm{C}$. Pemanasan dilakukan dalam atmosfer nitrogen bertekanan $300 \mathrm{~Pa}$. Suatu proses prenitriding, yang terdiri dari dua tahapan yaitu proses sputtering dan proses aktivasi. Pada proses sputtering, permukaan spesimen dibombardir oleh ion-ion nitrogen yang berasal dari plasma DC selama 30 menit. Gas nitrogen yang digunakan mempunyai laju aliran 160 $\mathrm{ml} / \mathrm{menit}$ dan diubah menjadi plasma dengan menggunakan tegangan bias sebesar $-500 \mathrm{~V}$. Selain itu selama proses pre-nitriding juga terjadi proses aktivasi sampel sehingga siap untuk proses difusi nitrogen pada kisi kristal titanium.

Proses utama nitriding pada penelitian ini berupa proses pemaparan spesimen menggunakan plasma yang dibangkitkan dengan generator RF dan DC yang dilakukan selama 4 jam. Pada proses ini digunakan campuran gas nitrogen dan gas hidrogen dengan laju aliran 160/40 ml/menit. Plasma yang digunakan dibangkitkan pada tegangan RF sebesar $250 \mathrm{~V}$ dan tegangan bias $\mathrm{DC}$ yang diatur pada nilai $-500 \mathrm{~V}$ atau $-600 \mathrm{~V}$. Pada penelitian ini diselidiki pengaruh tekanan gas terhadap peningkatan tingkat kekerasan permukaan titanium. Untuk itu dilakukan variasi terhadap tekanan gas pada nilai $75 \mathrm{~Pa}$, $50 \mathrm{~Pa}$, dan $30 \mathrm{~Pa}$ untuk masing-masing tegangan bias $-500 \mathrm{~V}$ atau $-600 \mathrm{~V}$.

\section{Observasi dan Pengukuran}

Morfologi permukaan dari sampel hasil nitridasi diobservasi dengan menggunakan peralatan scanning electron microscopy (SEM), Shimadzu SSX-550M. Tingkat kekerasan permukaan spesimen diukur dengan tester micro-Vickers hardness Akashi MVK-H1, Mitutoyo, Co. Ltd dengan pembebanan sebesar $0,5 \mathrm{~N}$ atau $50 \mathrm{gf}$. Hasil pengukuran tingkat kekerasan permukaan

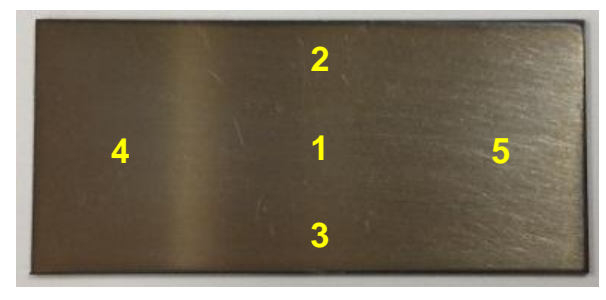

Gambar 3 Posisi untuk pengujian tingkat kekerasan titanium dengan metode microhardness Vickers

Sedangkan analisis struktur diobservasi dengan perangkat X-ray diffraction (XRD), Rigaku Ultima IV, Rigaku, Co. Ltd dengan menggunakan monokromator $\mathrm{Cu} \mathrm{K} \alpha$ yang mempunyai panjang gelombang $1.545980 \AA$. Sudut difraksi (20) dikontrol pada variasi sudut antara $3^{\circ}$ hingga $90^{\circ}$, dengan scanning step sebesar 0,02 derajat dan counting time sebesar 4 derajat/menit. Parameter dari profil hasil XRD dianalisis dengan menggunakan Rietveld refinement dari software Crystalsleuth. Standar parameter kisi yang digunakan adalah ICSD\#44390 (untuk $\alpha$-Ti), ICSD\#52521 (untuk $\omega$-Ti) dan ICSD\#152807 (untuk TiN).

\section{HASIL DAN PEMBAHASAN} Hasil

Perbedaan morfologi permukaan plat titanium murni sebelum dan sesudah proses nitriding dapat dilihat pada Gambar 4 yang merupakan hasil observasi SEM dengan perbesaran 1600 kali. Tampak bahwa terjadi perubahan pada morfologi permukaan dari struktur bergaris-garis menjadi struktur granular yang menunjukkan terjadinya perubahan struktur selama proses plasma nitriding. Terjadinya perubahan morfologi permukaan menunjukkan kemungkinan terjadinya perubahan mikrostruktur pada titanium murni setelah mengalami proses nitriding selama 4 jam. 

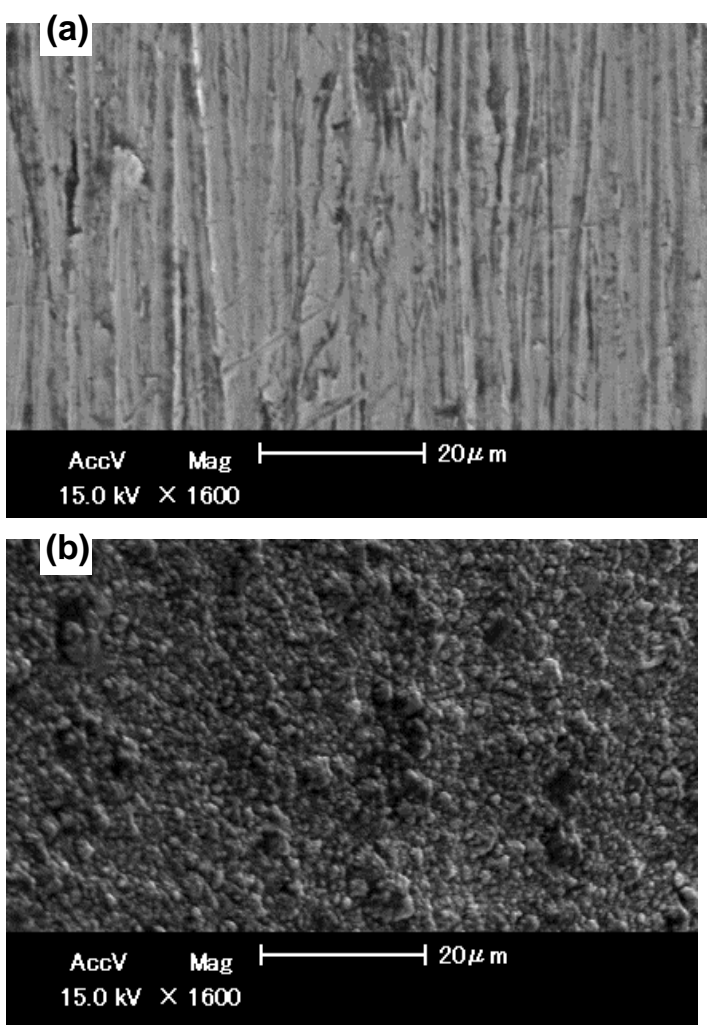

Gambar 4 Morfologi permukaan titanium sebelum dan sesudah proses nitriding pada suhu $450{ }^{\circ} \mathrm{C}$ pada tekanan $30 \mathrm{~Pa}$ dan tegangan bias DC -600 V selama 4 jam; (a) sebelum dan (b) sesudah proses nitriding

Hasil pengukuran tingkat kekerasan permukaan yang didapatkan melalui metode microhardness Vickers dengan pembebanan 0,5 N dinyatakan pada Tabel 1 berupa nilai rata-rata tingkat kekerasan dari 5 posisi yang diukur.

Di antara beberapa parameter yang digunakan untuk plasma nitriding dalam penelitian ini, tampak bahwa tekanan gas memainkan peran penting untuk peningkatan kekerasan permukaan untuk penggunaan nilai tegangan bias DC tertentu. Hal ini disebabkan oleh bertambah panjangnya mean free path untuk spesies aktif yang dihasilkan oleh plasma akan meningkatkan koefisien difusi, sehingga dengan penurunan tekanan gas pada proses akan meningkatkan peluang bagi atom nitrogen untuk terdifusi ke dalam kisi kristal titanium.
Tabel 1 Rata-rata tingkat kekerasan permukaan dari titanium murni dan 6 buah spesimen hasil nitridasi

\begin{tabular}{|c|c|c|}
\hline No & Perlakuan pada sampel & $\begin{array}{c}\text { Rata-rata } \\
\text { tingkat } \\
\text { kekerasan } \\
(\mathrm{HV}) \\
\end{array}$ \\
\hline 1. & Titanium murni sebelum nitridasi & 300 \\
\hline 2. & $\begin{array}{l}\text { Nitriding pada tekanan } 75 \mathrm{~Pa} \text {, } \\
\text { tegangan bias } \mathrm{DC}-500 \mathrm{~V}\end{array}$ & 416 \\
\hline 3. & $\begin{array}{l}\text { Nitriding pada tekanan } 50 \mathrm{~Pa} \text {, } \\
\text { tegangan bias } \mathrm{DC}-500 \mathrm{~V}\end{array}$ & 465 \\
\hline 4. & $\begin{array}{l}\text { Nitriding pada tekanan } 30 \mathrm{~Pa} \text {, } \\
\text { tegangan bias } \mathrm{DC}-500 \mathrm{~V}\end{array}$ & 596 \\
\hline 5. & $\begin{array}{l}\text { Nitriding pada tekanan } 75 \mathrm{~Pa} \text {, } \\
\text { tegangan bias } \mathrm{DC}-600 \mathrm{~V}\end{array}$ & 471 \\
\hline 6. & $\begin{array}{l}\text { Nitriding pada tekanan } 50 \mathrm{~Pa} \text {, } \\
\text { tegangan bias } \mathrm{DC}-600 \mathrm{~V}\end{array}$ & 620 \\
\hline 7. & $\begin{array}{l}\text { Nitriding pada tekanan } 30 \mathrm{~Pa} \text {, } \\
\text { tegangan bias } \mathrm{DC}-600 \mathrm{~V}\end{array}$ & 624 \\
\hline
\end{tabular}

Gambar 5 menyatakan perbandingan diagram XRD dari titanium murni sebelum dan sesudah proses nitriding pada tiga nilai tekanan yang berbeda untuk tegangan bias DC sebesar -600 V. Untuk menganalisis diagram XRD tersebut digunakan prosedur Rietveld untuk menentukan indeks Miller dari setiap peak yang diukur. Dari diagram pada Gambar 4 tampak bahwa beberapa peak yang dimiliki oleh titanium murni ( $\alpha$-titanium) berubah secara signifikan, terutama dapat

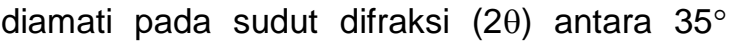
hingga $45^{\circ}$. Peak dari titanium murni pada sudut difraksi $38,6^{\circ}$ dan $40,3^{\circ}$ yang menggambarkan bidang kristal [0002] dan [10̄11] berubah menjadi sebuah peak baru pada sudut $39,5^{\circ}$ yang merupakan bidang kristal [1120] dan dikenali sebagai omega titanium. Selain itu hasil pengujian XRD pada sampel yang dinitridasi juga menunjukkan timbulnya peak baru yang dikenali sebagai titanium nitride (TiN). Beberapa peak TiN yang teramati pada diagram XRD yaitu pada sudut difraksi $2 \theta=37,2^{\circ}, 43,4^{\circ}, 61,5^{\circ}$, dan $74,4^{\circ}$ yang masing-masing bersesuaian dengan bidang kristal [111], [200], [220], dan [311]. 


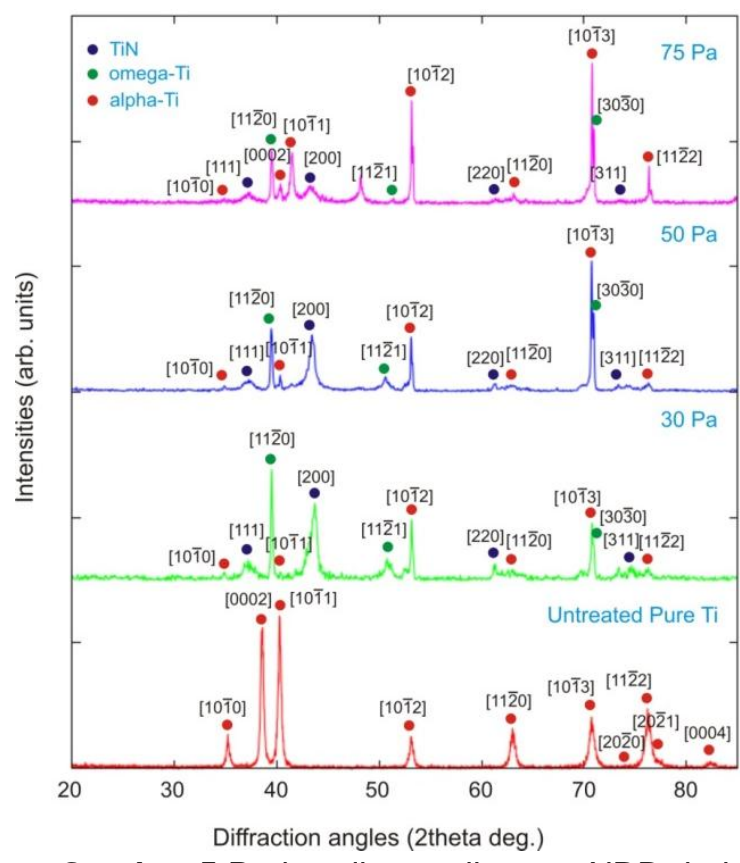

Gambar 5 Perbandingan diagram XRD dari titanium murni dengan 3 sampel yang dinitridasi pada tegangan bias $-600 \mathrm{~V}$
Berdasarkan hasil analisis terhadap diagram XRD juga didapatkan nilai parameter kisi dari tiap fase yang terdeteksi yang terdapat pada Tabel 2.

\section{Pembahasan}

Tampak dari hasil eksperimen yang telah dipaparkan di atas bahwa setelah proses nitriding dilakukan terbentuk suatu lapisan permukaan yang mengandung yang terdeteksi sebagai TiN. Dari hasil penghitungan menggunakan persamaan Scherrer, didapatkan nilai crystalline size untuk TiN yang terbentuk antara 6,43 hingga 22,48 nm. Nilai ini menggambarkan bahwa TiN yang terbentuk adalah suatu fine precipitation. Presipitat TiN yang berukuran nano ini terjadi karena reaksi penggabungan (coalescence) antara nitrogen dan titanium yang terbentuk pada permukaan sampel yang dinitridasi.

Pembentukan presipitat TiN dipengaruhi oleh parameter plasma yang digunakan yaitu tekanan gas dan tegangan bias DC. Semakin rendah tekanan gas yang digunakan maka peak TiN yang terbentuk semakin tinggi. Hal ini berarti konsentrasi TiN dalam sampel meningkat. Pada proses nitriding dengan plasma, penurunan tekanan gas akan

Tabel 2 Parameter kisi dari tiap fase yang terdeteksi pada diagram XRD untuk titanium murni dan 6 sampel hasil nitridasi

\begin{tabular}{|c|c|c|c|c|c|c|c|c|}
\hline \multirow{2}{*}{ No. } & \multirow{2}{*}{ Perlakuan Sampel } & \multicolumn{3}{|c|}{ Fase $\alpha-\mathrm{Ti}$} & \multicolumn{2}{|c|}{ Fase $\omega-\mathrm{Ti}$} & \multirow{2}{*}{\multicolumn{2}{|c|}{$\begin{array}{c}\text { TiN } \\
\begin{array}{c}a=b=c \\
(\AA)\end{array} \\
(\AA)\end{array}$}} \\
\hline & & $\begin{array}{c}a=b \\
(\AA)\end{array}$ & $(\stackrel{C}{\AA})$ & $\mathrm{c} / \mathrm{a}$ & $\begin{array}{l}a=b \\
(\AA)\end{array}$ & $\begin{array}{l}\mathrm{C} \\
(\stackrel{\circ}{\mathrm{C}})\end{array}$ & & \\
\hline 1. & $\begin{array}{l}\text { Titanium murni sebelum } \\
\text { nitridasi }\end{array}$ & 2.9531 & 4.6826 & 1.5857 & & & & \\
\hline 2. & $\begin{array}{l}\text { Nitriding pada tekanan } 75 \mathrm{~Pa} \text {, } \\
\text { tegangan bias } \mathrm{DC}-500 \mathrm{~V}\end{array}$ & 2.9780 & 4.7150 & 1.5834 & 4.6320 & 2.8300 & 0.6110 & 4.1582 \\
\hline 3. & $\begin{array}{l}\text { Nitriding pada tekanan } 50 \mathrm{~Pa} \text {, } \\
\text { tegangan bias } \mathrm{DC}-500 \mathrm{~V}\end{array}$ & 2.9510 & 4.6650 & 1.5808 & 4.6572 & 2.8754 & 0.6174 & 4.3535 \\
\hline 4. & $\begin{array}{l}\text { Nitriding pada tekanan } 30 \mathrm{~Pa} \text {, } \\
\text { tegangan bias } \mathrm{DC}-500 \mathrm{~V}\end{array}$ & 2.9450 & 4.6650 & 1.5840 & 4.6100 & 2.8100 & 0.6095 & 4.2520 \\
\hline 5. & $\begin{array}{l}\text { Nitriding pada tekanan } 75 \mathrm{~Pa} \text {, } \\
\text { tegangan bias } \mathrm{DC}-600 \mathrm{~V}\end{array}$ & 2.9527 & 4.6830 & 1.5860 & 4.6517 & 2.8643 & 0.6158 & 4.3950 \\
\hline 6. & $\begin{array}{l}\text { Nitriding pada tekanan } 50 \mathrm{~Pa} \text {, } \\
\text { tegangan bias } \mathrm{DC}-600 \mathrm{~V}\end{array}$ & 2.9520 & 4.6680 & 1.5813 & 4.6499 & 2.8580 & 0.6146 & 4.2870 \\
\hline 7. & $\begin{array}{l}\text { Nitriding pada tekanan } 30 \mathrm{~Pa} \text {, } \\
\text { tegangan bias } \mathrm{DC}-600 \mathrm{~V}\end{array}$ & 2.9450 & 4.6610 & 1.5827 & 4.6320 & 2.8370 & 0.6125 & 4.2590 \\
\hline
\end{tabular}


meningkatkan densitas ion dalam plasma, menumbuk permukaan titanium. Sementara itu, energi dari ion nitrogen yang menumbuk permukaan titanium ditentukan oleh besarnya tegangan bias DC yang digunakan. Semakin besar nilai tegangan bias DC, maka energi kinetik ion nitrogen yang menumbuk permukaan juga akan semakin besar [8]. Hal ini ditunjukkan pada data hasil percobaan yaitu pada penggunaan tekanan gas $30 \mathrm{~Pa}$ dan tegangan bias DC $-600 \mathrm{~V}$, diperoleh tingkat kekerasan permukaan yang tertinggi yang ditandai oleh konsentrasi TiN yang tertinggi pula.

Dari hasil analisis XRD, titanium murni mempunyai struktur kristal hexagonal closedpacked (HCP) yang dikenal sebagai $\alpha-T i$ dengan parameter kisi yang mempunyai nilai a $=2,95 \AA$ dan $\mathrm{C}=4,68 \AA$ sehingga didapatkan nilai c/a sebesar 1,58 [9]. Dari hasil data yang ditunjukkan pada sampel-sampel setelah proses nitridasi, nilai c/a relatif tidak berubah berubah dengan kisaran nilai sebesar 1,58 yang sangat sesuai dengan nilai teoritis. Di lain pihak, terdeteksi adanya fase baru dari titanium yaitu omega titanium $(\omega-\mathrm{Ti})$ yang mempunyai struktur primitive hexagonal dan dikenal sebagai suatu fase metastabil dari titanium yang biasanya terbentuk akibat tekanan hidrostatis tinggi yang mengenai kristal titanium. Fase omega yang terbentuk pada sampel yang dinitridasi mempunyai parameter kisi yang mempunyai nilai a berkisar antara 4,61 hingga 4,65 $\AA$ dengan nilai c berkisar antara 2,81 hingga $2,88 \AA$ sehingga didapatkan nilai c/a sekitar 0,61 [9]. Terjadinya perubahan fase ini ternyata sangat berpengaruh terhadap pembentukan TiN pada sampel hasil nitridasi.

Pembentukan TiN sangat dipengaruhi oleh proses difusi yang terjadi pada saat proses nitriding berlangsung. Nitrogen akan terdifusi ke dalam matriks kristal titanium dengan menempati posisi interstisi sebagai larutan padat (solid solution). Hal ini karena ukuran atom nitrogen sebesar 0,92 A masih jauh lebih kecil daripada ukuran atom titanium. Proses difusi interstisi sangat dipengaruhi oleh kelowongan pada struktur kristal dan koefisien berarti akan semakin banyak ion nitrogen yang difusi dari nitrogen [10]. Nilai koefisien difusi sangat bergantung pada suhu proses.

Karena proses nitriding pada penelitian ini dilakukan pada suhu $450^{\circ} \mathrm{C}$, dimana suhu ini masih sangat jauh di bawah suhu transisi untuk pembentukan beta titanium ( $\beta$-Ti) yaitu sebesar $883{ }^{\circ} \mathrm{C}$, maka dapat dikatakan bahwa tidak mungkin terbentuk fase $\beta$-Ti pada penelitian ini. Pembentukan fase $\beta-\mathrm{Ti}$ pada proses nitriding akan meningkatkan koefisien difusi dari nitrogen, sehingga akan semakin besar konsentrasi nitrogen yang terkandung pada kristal sebagai hasil proses difusi interstisi. Beberapa hasil penelitian terdahulu menyatakan bahwa TiN biasanya baru akan terbentuk pada suhu proses nitriding di atas $800{ }^{\circ} \mathrm{C}$, karena TiN baru akan terbentuk jika konsentrasi nitrogen yang terkandung pada kisi kristal cukup besar [8] [9].

Karena fase $\beta$-Ti tidak terbentuk, maka faktor kelowongan pada struktur kristal yang akan mempengaruhi jumlah atom nitrogen yang akan terdifusi. Hasil penelitian terdahulu menyatakan pada fase $\omega-\mathrm{Ti}$ mempunyai struktur yang lebih terbuka dibandingkan terhadap struktur $\alpha$-Ti. Nilai packing ratio sebesar $\sim 0,57$ untuk $\omega$-Ti secara substansial lebih kecil jika dibandingkan dengan $\alpha$-Ti yang mempunyai nilai packing ratio sebesar $\sim 0,74$ [9]. Hasil penghitungan berdasarkan pemodelan struktur kristal dari $\alpha-\mathrm{Ti}$ dan $\omega$-Ti menunjukkan adanya peningkatan prosentase dari void space dari $79,96 \%$ menjadi $89,74 \%$. Gambar 7 menunjukkan kemungkinan posisi difusi interstisi pada struktur $\alpha-\mathrm{Ti}$ dan $\omega-\mathrm{Ti}$ [11].

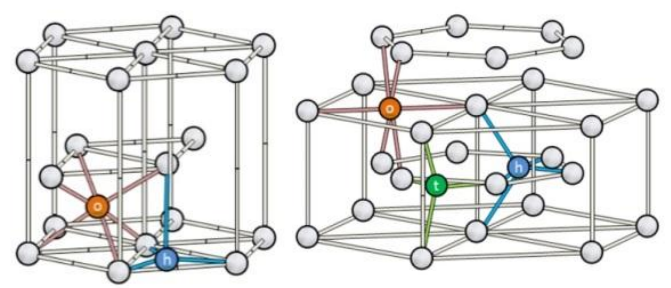

Gambar 7 Kemungkinan posisi difusi interstisi pada kisi kristal untuk fase $\alpha$-Ti dan $\omega$-Ti. Titik yang berwarna merah, biru, dan hijau masing-masing menunjukkan posisi oktahedral, heksahedral, dan tetrahedral. 
Selain itu, ukuran kelowongan kisi (vacancy site) juga mempengaruhi proses difusi, seperti ukuran kelowongan kisi oktahedral yang lebih besar dibandingkan dengan kelowongan kisi tetrahedral akan menyebabkan nitrogen terlarut cenderung menempati kelowongan kisi oktahedral karena akan membutuhkan energi difusi yang lebih rendah [10] [7].

Akhirnya dapat dikatakan bahwa terbentuknya presipitat TiN dan larutan padat nitrogen di dalam matriks titanium merupakan faktor penentu terhadap peningkatan kekerasan permukaan titanium. Dan hasil terpenting yang didapat pada penelitian ini adalah bahwa mekanisme pengerasan yang terutama ditentukan proses pembentukan TiN biasanya terjadi pada proses yang suhunya tinggi (di atas $800{ }^{\circ} \mathrm{C}$ ) $[2,4,5,3][1,3,5,6]$, ternyata dapat dicapai melalui proses nitriding dengan suhu rendah yaitu $450{ }^{\circ} \mathrm{C}$ dengan menggunakan plasma densitas tinggi selama 4 jam.

\section{KESIMPULAN}

Berdasarkan hasil penelitian dari proses nitriding terhadap titanium murni yang dilakukan pada suhu rendah dengan menggunakan plasma densitas tinggi yang dibangkitkan dengan generator RF dan DC dapat disimpulkan bahwa:

1. Penambahan perangkat hollow cathode dapat digunakan untuk mewujudkan proses nitriding pada suhu yang cukup rendah yaitu $450^{\circ} \mathrm{C}$.

2. Terjadi perubahan fase dari $\alpha$-Ti menjadi $\omega$ $\mathrm{Ti}$ pada penggunaan tekanan gas yang rendah disertai tegangan bias DC yang tinggi.

3. Terbentuknya fase $\omega-\mathrm{Ti}$ meningkatkan koefisien difusi nitrogen pada matriks titanium yang menyebabkan terbentuknya presipitat TiN.

4. Terbentuknya presipitat TiN sekaligus larutan padat nitrogen menyebabkan tingkat kekerasan permukaan titanium murni mengalami peningkatan yang signifikan.

\section{UCAPAN TERIMA KASIH}

Penulis sangat berterima kasih kepada Prof. Tatsuhiko Aizawa dari Shibaura Institute of Technology, Tokyo, Japan yang telah mengusahakan beasiswa dari JASSO dan memberikan fasilitas saat penulis melaksanakan penelitian di LLC Nano Film \& Coat Laboratory, Ota-ku, Japan dan semua fasilitas pengujian sampel di kampus Shibaura Tamachi dan Toyosu. Demikian juga atas supervisi dan bimbingan selama penulis melaksanakan penelitian di Jepang. Penulis juga berterima kasih kepada Lembaga Penelitian ASMAT, Universitas Brawijaya, yang mendanai melalui Program Hibah Kerjasama Luar Negeri JSPS Dikti dengan surat perjanjian nomor 033/SP2H/LT/ DRPM/2/2016 sehingga penelitian ini dapat terlaksana.

\section{DAFTAR PUSTAKA}

[1] Buijs, K. and V.L. Stainless, V.L., 2008, Characteristic and uses of titanium, Stainless World, pp. 1-4.

[2] 1- [2] Zhecheva, A., Wei Sha, Malinov, S. and Long, A., 2005, Enhancing the microstructure and properties of titanium alloys through nitriding and other surface engineering methods, $J$. of Surface \& Coating Technology 200, pp. 2192-2207.

[3] Koyuncu, E., Kahraman, F. and Karadeniz, O., 2009, Investigation of surface properties of high temperature nitrided titanium alloys. J. of Achievements in Material and Manufacturing Engineering, vol. 37 (2), pp. 434-441.

[4] Yoshida, M., Ichiki, R. and Utsumi, N., 2013, Surface hardening of titanium using gas nitriding, J. of Precision Engineering and Manufacturing, vol. 14, no. 6, pp. 971976.

[5] Yilmazer, H., Yilmaz, S. and Acma, E., 2009, Treatment of surface properties of titanium with plasma (ion) nitriding, Article in Defect and Diffusion Forum, vol. 283286, pp. 401-405.

[6] Tong, W.P., Han, Z., Wang, L.M., Lu, J. and Lu, K., 2008, Low-temperature nitriding of $38 \mathrm{CrMoAl}$ steel with a nanostructured surface layer induced by surface mechanical attrition treatment, $J$. of Surface \& Coating Technology 202, pp. 4957-4963. 
[7] Aizawa, T. and Sugita, Y., 2011, [10] Gicouel, A., Laidani, N., Saillard, P. and Development of RF-DC plasma system for nitriding of aluminium alloys, In ICMCTF2011, Vol. 1, pp. 47-48.

[8] Brading, H.J., Morton, P.H., Bell, T., and Earwaker, L.G., 1992. Plasma Nitriding with Nitrogen, Hydrogen, and Argon Gas Mixtures: Structure and Composition of Coatings on Titanium, Surface Engineering, vol. 8 (3), pp. 206-212.

[9] Errandonea, D., Meng, Y., Somayazulu, M. Amouroux, J., 1990, Plasma and nitrides: application to the nitriding of titanium, $J$. Pure \& Applied Chem., vol. 62, no. 9, pp. 1743-1750.

[11] Hennig, R.G., Trinkle, D.R., Bouchet, J., Srinivasan, S.G., Albers, R.C., and J.W. Wilkins, J.W., 2005, Impurities block the $\alpha$ to $\omega$ martensitic transformation in titanium, Nature Materials, vol. 4, pp. 129-133. and Häusermann, D., 2005, Pressureinduced $\alpha \rightarrow \omega$ transition in titanium metal: A systematic study of the effect of uniaxial stress, Physica B, vol. 355, pp 116. 